\title{
Exploring the Phenomenon of Youthnization of Poverty in South Africa
}

\author{
Prof. S. M. Kang'ethe \\ University of Fort Hare, Department of Social Work and Social Development, \\ Box X1314, Alice. 5700, South Africa \\ Email: skangethe@ufh.ac.za \\ Mr. Tatenda Manomano \\ PhD in Social Work Student, University of Fort Hare, Box X1314, Alice. 5700 \\ Email:200706055@ufh.ac.za
}

\section{Doi:10.5901/mjss.2014.v5n27p1437}

\section{Abstract}

Indubitably, the preponderance of poverty by the youth, or the so called youthnization of poverty is a cankerworm that needs to be annihilated especially in countries of the developing world if youth participation in socio-economic development is to make a significant score in their countries. The aim of this article is, through a literature review methodology, to discuss the underpinning factors motivating the phenomenon of youthnization of poverty in South Africa. The following factors have been found to contribute to youthnization of poverty in South Africa: burgeoning statistics of unemployment; lack of infrastructural support for the youth; poor skill development among the youth; and increasing state of dependence syndrome. The following factors have been suggested to mitigate or reduce youthnization of poverty: mobilize funding for the youth, craft youth friendly policies; and countries engaging in plausible research to find out plausible ways of mitigating or annihilating youthnization of poverty altogether.

Keywords: Preponderance of poverty, Youth friendly Policies, burgeoning unemployment statistics, Poverty, skill development, dependence syndrome

\section{Operational Definition}

\subsection{Youthnization of poverty}

The word youthnization has been used to refer to presence, drive, magnitude, scope, impacts and factors associated with activities of youths in a particular country. According to the United Nations (UN), youth are people between the age 1524; while the African Youth Charter identifies the youth as people lying between the ages of 15 and 35 (CARMMA, 2014). Therefore just as concepts such as youthnization of HIVIAIDS that indicates the magnitude of youth infection to the disease, youthnization of poverty refers to the phenomenon of poverty among the youth

\section{Introduction and Background}

Indubitably, poverty is a very dangerous evil that has confronted humanity in a pervasive way globally and especially in the developing part of the world (Moore, 2005). Poverty is huge in South Asia countries affecting 134-188 million people; and Sub Saharan African countries (Moore, 2005). A lot of efforts have been put into place across decades with many committees and commissions being formulated to foster a formidable front against poverty. Regrettably, the war appears to be a protracted one, taking decades if not generations to be subdued (Tanner, 2014; UN, 2014). It is therefore pertinent to understand the magnitude and underpinnings of poverty and its possible ramifications. Exploring deeply the underpinnings of poverty in South Africa can form an optimistic ray of hope that poverty that undermines youth empowermrnt can be mitigated, if not annihilated alotogether (Kang'ethe, 2014a).

Unarguably, poverty is a social evil and a form of deprivation that can either be relative or absolute (Kang'ethe, 2009). Absolute poverty is a form of deprivation whereby the subsistence is actually below the minimum requirements for physical well-being. Although the index for absolute poverty may be debated about, it is usually based on a quantitative scale and in a broader sense it is taken to include issues such as income as well as goods and services (Hulme, Moore \& 
Shepherd 2001; Kang'ethe, 2009). On the other hand, relative poverty entails a circumstance or experience in which the income or consumption level is below the prevailing or surrounding location where they reside or a fraction of the national country average (Hulme, Moore \& Shepherd, 2001). Since most discussion on statistics focus or refer to absolute poverty, this paper and by extension these researchers will also focus on absolute poverty. In delving more deeper with the conceptualization of poverty, it is pertinent to borrow a leaf from the United Nations demarcations and expressions of what constitute poverty. The United Nations demarcate poverty into clusters. The first cluster concerns a lack of money which can also translate to a want in consumption among other things. The second cluster concerns material want such as a lack of basic wealth and a lack of low quality of other assets such as shelter, clothing, furniture, personal means of transport, radios, television. This can also translate to poor access to services. The third cluster is derived from Amartya Sen, one of the scholars in the area of Capability Approach and indentifies it as a capability deprivation. This entails what a human being can or cannot do, and can or cannot be, and is also known as human capabilities such as skills, abilities and even respect attained from society (UNDP Internation Poverty Centre, 2006). The fifth last cluster identifies poverty as indicating people who are in various state of miseries such as being poor, marginalized, vulnerable, excluded or deprived. Development is therefore seen as a translation from ill-being to well-being. III-being refers to conditions of powerlessness, insecurity, physical weakness/illness, material lack or poverty and bad social relations, while a state of well-being refers to freedom of choice and action, security, good social relations, enough assests and services that guarantees good life, physical well being and security among other things (UNDP International Poverty Centre, 2006). Moreover and interestingly, poverty is also viewed as multi-dimensional in that those who are chronically poor are poor in several ways, not only in terms of income, but may also be facing food insecurity every year and with low levels of assets among other things (Hulme, Moore \& Shepherd, 2001). All these dimensions are unfortunately hitting very hard on the young people because they are in a stage from child-hood dependence to individual independence. This state has a serious economic impact on countrries' state of GDP. In South Africa, because of the huge number of the youth swimming in a sea of poverty and yet the country is one of tyeneconomically sound one in Africa, youth poverty it has got an impact on labour market participation (Moleke, 2014). This implies that without requisite assistance, they can easily fall victims to inaccessibility to learning institutions, markets, employment opportunities and public services. The situation is also likely to increase their dependence from significant others such as their parents (UNESCO, 2011). In terms of employment, they are the most fired and the least hired and accrue unreliable work contracts and struggle severely to access funding for businesses they may intend to set up. Statistics in 2013 pertaining to youth unemployment indicate that $58 \%$ of youth were unemployed (NUMSA 2014). Schokingly, they are also more than twice to be unemployed than adults (UNESCO, 2011). According to UNESCO (2011: 01), poverty "hits young people particularly hard: an estimated 515 million young people aged 15 to 24 people live on less than two dollars a day-that is nearly $45 \%$ of all youth". This calls for more efforts and commitment from the global village in terms of rebuilding and advancing the development of the youth (UNESCO, 2014). The vulnerability and unbearable circumstances facing the youth are even widespread and grave in the developing world especially in rural areas (UNDP, 1995). Inarguably, some categories of the youth are even more vulnerable than the general youth population. Suchgroups includes young women, youth with diabilities, youth in armed conflict regions, indeginous youth and youth living as refugees (UN-DESA 2014; Mail \& Guardian 2011). Statistics pertaining to youth poverty in South Africa reveal that close to two thirds of the youth live in households with monthly percapita income below R650, and 35\% live in households where no one is employed (Ensor, 2012).

\section{Article Rationale}

The issues of the pervasiveness of poverty among the youth continue to attract a lot of attention and take cetre stage globally, regionally and nationally with a goal to promulgate possible alternatives to address the problems they face. The need to achieve sustainable development and eradication of poverty as envisaged by Millenium Development Goal (MDG) number 1 is also central to the emergent steps and efforts that are being taken to address the state of youthinization of poverty. The advocacy for the rights and socio economic development of the youths has also been the motivating factor for these authors to craft this discourse and debate based paper. This is with the hope of putting forward possible solutions that can assist towards empowering and developing the youth in the face of poverty they deserve.

\section{Methodology}

This paper is a literature review one and has consulted UN documents, journals, books, and the researchers' knowledge on the domain. The paper identifies the possible contributing factors to the pervasiveness of poverty and the factors that contribute to the lagged out process in winning the war against that poverty among the youth in South Africa. The 
literature has pittied and debated the developmental efforts against the challenges faced by the youth.

\section{Factors Underpinning Youthnization of Poverty in South Africa}

\subsection{Burgeoning statistics of youth unemployment in South Africa}

Although there is no country which is immune from state of unemployment, whether developed or developing, the state appears grave in developing countries. This is perhaps due to undeveloped industries, private and business sector, NGO sector and probably due to dearth of skills to taps and harness the indigenous resources. Lack of supporting infrastructure for the youth to venture into sustainable business undertakings also constitute factors of massive poverty in many countries of the developing world. All these factors above could explain why developing countries have remained poor and if situations do not change the poverty levels can be endemic to stifle youth empowermrnt and thyeerfore make their future bleak (Kang'ethe \& Serima, 2014; Kang'ethe, 2014a; Mulinge \& Mufune, 2003).

Statistically, unemployment is very high in South Africa. It is unfortunate that although a significant number of people in South Africa are swimming in wealth and riches, a greater number of black South Africans are living in conditions of severe deprivations with the youth facing a bleak future because of the high levels of unemployment. In 2013 , statistics indicate that $58 \%$ of youth were unemployed (NUMSA, 2014). The high rate of unemployment in South Africa is argued to be a development from Apartheid (Midgely, 1999) while the Post Global 2008 economic meltdown worsened the situation with policy and programmatic weaknesses motivating the rise of unemployment in South Africa (Fin 24, 2014). Shockingly, South Africa is known to be the country with the third highest levels of unemployment of youth between the ages of 15-24 based on theWorld Economic Forum (WEF) and Global Risk 2014 Report (Fin 24, 2014). In the same vein, the huge costs for higher education coupled with high costs of living and huge debts have left a lot of aspiring youth in conditions of despondency and despair (Fin 24, 2014). Other researchers indicate that South Africa's high youth unemployment is a time ticking bomb that can destabilize the country politically. This is because events that have taken place in North Africa and some European countries reveal that job creation for the youth needs to be prioritized and effectuated (NUMSA, 2014). Employment is one critical source of income for many households while to most people it enhances dignity,self-esteem and independence. Employment facilitates the generation and saving of capital. Hence the lack of jobs in South Africa further marginalizes the youth leaving them without hope and certainty (Blumenfeld, undated). It is further proposed that proven, tried and tested approaches from the international community such as the German dual apprenticeship program among others be taken as lessons to apply in addressing youth unemployment in South Africa. such as the (NUMSA, 2014).

\subsection{South Africa youth lack infrastructural support to sustain their livelihood.}

Population statistics of young people indicate that there are 19.5 million people in South Africa constituting $38 \%$ of the total population (CDE, 2014: 02). Two thirds of the youth reside in four of South Africa's provinces namely Gauteng, Eastern Cape, Kwazulu Natal and Limpopo, while the rest reside in other provinces with most of them residing in urban areas and a few in the rural areas (UNFPA, 2013). Many youth are concentrated in Soweto (375 000), Johannesburg CBD (307 000), Pretoria's CBD (205 000), among other things (CDE, 2014: 02). Gravely, the youths in South Africa face daunting challenge to eke for a sustainable living. Regrettably, both the government and the non-government agencies have not mobilized resources to assist the youth achieve sustainable livelihood. This is ironical in South Africa as the country is one of the strongest economic power house in Africa and one that can afford to finance the World Banks and International Monetary Fund, and yet not affording to ably initiate strong infrastructural support for its youth (National Planning Commission, 2014). Increasingly, there is perceptions from the youth themselves from various African countries as well as from other quarters that the youths have not adequately been taken care of by their governments (Kang'ethe, 2014a). No meaningful interventions geared towards youth development and sustainable livelihood have been put in place. The so called Umsombomvu youth funds do not appear to reach a wider cross section of the youth especially those in the rural areas (Parliamentary Monitoring Group (PMG), 2007). Perhaps this is why Kang'ethe (2014a) indicates that failure to adequately take care of the youth in many African countries present a lost opportunity. This is because the youths have energy that can positively be harnessed and tapped to contribute meaningfully to their countries Gross Domestic Production (GDP) (Todaro \& Smith, 2006)

Apparently, most youth in African countries including South Africa feel discriminated, condescended especially by their adult significant others and are only used by the adults for the adults' self-aggrandizements. For example, in countries such as Kenya, youths have been strong targets from the politicians who promise them many things but never 
live to fulfill the promises (National Planning Commission 2011; Kang'ethe, 2014a). While the government needs to be commended for its immense effort in taking care of the elderly and those in needs of care through accessing them different grants, the youth should also be viewed as a vulnerable but stronger individuals who through meaningful engagements and interventions can be able to support themselves and probably reduce the number of individuals the government has to offer food and accommodation. It is a pity that the government has to provide Reconstruction and Development (RDP) houses and yet if they can be developed, they could possibly be engaged in economically gainful government initiated interventions to earn their own resources that can lead to their sustainability. This could in a way also reduce the country's state of dependence syndrome that threaten to weaken the country's human capital. Such interventions could possibly also reduce societal crime rates and youth's indulgence in drugs (Kang'ethe \& Manomano, 2014; Kang'ethe, 2014a, b).

\subsection{Poor skill development Among South African Youth}

It is a naked fact that in many occupational settings, there is an inextricable relationship between skills development and employment opportunities, with those who are poorly equipped with skills finding it difficult to get jobs, or competently be able to tap and harness the indigenous resources in their social milieu. This places the importance of training as an impetus to socio-economic development (UNAIDS, 2001; Kang'ethe, 2014c). Indubitably, South African youth are very vulnerable as pertains their state of unemployment. Most of these are attributed to the lack of skills and apathy to move on in life (Trevithick, 2004)

Due to the high rates of poverty and its ramifications, most of the youth do not manage to make it to finish high school let alone University (Mtshali, 2013). Therefore they suffer from poverty and its ramifications making them not to take advantage of free schooling in either the secondary or university. Usually, when people live in poverty stricken environments, access to food becomes the primary goal while other factors such as schooling for the future are either secondary or are obscured altogether. This in South Africa is the unfortunate and perfidious effects of poverty that continue to be a serious bottleneck to socio and economic development (Ndonga, 2012; Monama, 2006) These authors challenge the government to invest more on youth projects especially training them in various cadres of professions so that they can be employable, or be in a position to create their own jobs. This is why Kang'ethe and Manomano in their article on RDP challenges the government to equip the RDP house residents with informal training of various manual based professions if they are to come out of poverty and stop depending on government assistance in form of grants or accommodation (Kang'ethe \& Manomano, 2014).

Furthermore, some of the institutions such as high schools and Universities are located far from the locations of the vulnerable and needy, this further making their access to these valuable institutions a daunting and an uphill task. A good example can be the youth from the Golf Course village that have to walk very far to access school (Manomano, 2013). Statistics from the Department of Social Development indicate that many $60 \%$ of the South Africans fail to complete grade 12 (Spaul, 2014), while others fail to complete their higher education (McGregor 2007). Thus although an outcry can be noised abroad about unemployment, the issue of skills and abilities is another venom to the socio-economic development of the youth in South Africa (Department of Social Development (DoSD), 2012).

\subsection{Dependency syndrome among the youth is another contributing factor}

The role that the youth play in their own path to obtain a meaningful survival is also very critical as everything may not be done for them by the government or other bodies. It is therefore critical that human resource develop among the youth so that they are able to develop themselves and therefore contribute to the country's socio and economic development (Todaro \& Smith, 2006). Other researchers indicate that some youth survive on the goodwill of their parents. This state of affairs creates a cyclical dependence syndrome whereby the youth will not take responsibility to develop themselves and their lives but will rather wait and sit for the parents to do everything for them (Kang'ethe, 2014b). In a world where everything is becoming expensive and broken families becoming rampant, this scenario overburdens the already overwhelmed South African government financially (Chigunta, undated). These authors think that there is need for introspection and review of the support given to parents to educate their families and especially their children and the communities. This can be done in partnership with the Non-Governmental Organizations (NGOs) such as FAMSA among others. 


\section{Strategies to Address Youthinization of Poverty}

In light of the many problems that challenge the youth in South Africa, the following have been put forward to address the poverty that confronts them.

- Mobilizing funding from the government and non-government as well as international bodies towards skills development and employable apprentice programmes among other things. This will market the youth and enhance independence among other things.

- Crafting policies and programmes towards enabling the youth to starts their own entrepreneurships, businesses and other self-development and enrichment interests. This will not only grow local investment but also develop and equip the youth

- There is need for an empirical investigation that will explore the effectiveness of the policies and programmatic interventions in addressing youth poverty. Such an investigation will need to adopt both qualitative and quantitative enquiry to ensure that the data is reliable and trustworthy among other things.

\section{Conclusion}

Youthnization of poverty is a global cankerworm that appears to stifle development of especially the developing countries. Optimistically, the phenomenon of youthnization of poverty can only be tackled if the government put in place strong policy environment that will prioritize mobilizing resources to empower the youth. Equipping the youths with various kinds of skills can help them improve their chances of employability and also ability to carry out businesses. In most developing countries, since the youths constitute a larger population segment in each country, governments should apportion a lion's share of their countries' budget towards youth empowerment. It is critical that all the underpinnings negatively affecting the youth such as poverty, diseases such as HIVIAIDS are also tackled so that the phenomenon of youthnization of poverty can be weakened, or annihilated altogether. Since South Africa is a country endowed with resources, prioritizing resources towards youth empowerment can help secure their future and therefore also increase their participation in the country's economic development.

\section{References}

Blumenfeld J (undated). Youth unemployment in South Africa and the Wage Subsidy 'Debate'.

Chigunta $\mathrm{F}$ (undated). The socio-economic situation of youth in Africa: Problems, Prospects and Options.

CARMMA (2014). The African Youth Charter. Available on www.carmma.org. Accessed on 03/09/2014

CDE (2014). Young People and opportunity in South Africa's cities. Available at www.sablenetwork.com. Accessed on 01/09/2014

DoSD (2012). Policy Framework on Social Security for Youth in South Africa. Available at www.socdev.org.za. Accessed on 13/4/2014

Ensor L. (2012). Report highlights stark poverty young South Africans face. Available at Business BDlive.co.za. Accessed on 13/4/2014

Fin 24 (2014). SA youth unemployment $3^{\text {rd }}$ highest in the world. Available at www.fin24.co.za. Accessed on 13/4/2014

Hulme D, Moore K \& Shepherd, A. (2001). Chronic Poverty: meanings and analytical frameworks. International Development

Department, Institute of Development Policy and Management. CPRC Working Paper 2

Kang'ethe, S.M (2009). Challenges impacting on the quality of care to persons living with HIVIAIDS and other terminal illnesses in Botswana. Journal of Social Aspects of HIVIAIDS (Sahara). Vol. 6 (1) March 2009. Pp 24-32.

Kang'ethe S.M. (2014a). Exploring Lost and Available Opportunities for Youth Empowerment in selected African Countries. Journal of social Science. 39(1): 1-8

Kang'ethe, S.M (2014b). Exploring social work gaps with examples from South Africa and Botswana: In the press of Journal of Social Sciences.

Kang'ethe, S.M (2014c) An exploration of the panacea of training palliative caregivers in Botswana community home based care programmes. An empirical case study perspective. In the press of Journal of Social Sciences.

Kang'ethe, S.M \& Tatenda Manomano (2014). Evaluating the Ownership Spirit Displayed by the Golf Course RDP Housing Programme Beneficiaries with evidence Emanating from the 2011-2013 Research Study. Journal of Human Ecology. 46(1): 11-19

Kang'ethe, S.M \& Joseph Serima (2014k). Exploring Challenges \& Opportunities Embedded in Small-Scale Holdings in Zimbabwe. J Hum Ecol, 46 (2):177-185(2014).

Macgregor, K. (2007). South Africa: Student drop-out rates alarming. Available at www.universityworldnews.com. Accessed on $13 / 08 / 2014$

Mail \& Guardian (2011). Poverty \& Inequality in South Africa. Available at www.my.co.za. Accessed on 01/09/2014

Manomano, T (2013). The perceptions of the Reconstruction and Development Programme (RDP) Housing beneficiaries in South Africa on the extent to which the project meet their housing needs. The case of Golf Course estate in Alice Town. Unpublished Masters of Social work Dissertation, University of Fort hare

Midgley.J. (1999). Social Development in social work: learning from global dialogue. In C. 
Ramanathan \& R. Links (eds). All our futures. Principles and resources for social work practice in a global era (pp193-205). Belmont, CA: Brooks/Cole.

Moleke, P. 2014. Lack of employment security affects youth's social protection. Available at www.mg.co.za. Accessed on 01/09/2014 Monama, M. (2006). Poverty punishes South African Workers. City Press

Moore, K. (2005). Thinking about youth poverty through the lenses of chronic poverty, life course poverty and inter-generational poverty. CPRC Working Paper 57. Manchester, United Kingdom. Available at www.chronicpoverty.org. Accessed on 04/09/2014

Mulinge MM \& Mufune, P (2003). Debt relief initiatives and poverty alleviation. Lessons from Africa. African Institute of South Africa Mtshali, N. (2013). Only 15\% of SA university students graduate. Available at www.iol.co.za. Accessed on 13/08/2014

National Planning Commission (2011). National Development Plan Vision for 2030. Available on www.npconline.co.za. Accessed on 04/09/2014

National Planning Commission (2014). The future of towns and cities. Available at www.npconline.co.za. Accessed on 03/09/2014

Ndonga, M. M (2012). An Assessment of the Impact of HIVIAIDS on the children's Right to education: A case study of HIVIAIDS Orphans and Vulnerable Children in the Amthole District. Masters Dissertation. University of Fort Hare

NUMSA (2014). South Africa's Youth unemployment crisis. Available at www.numsa.org.za. Accessed on 13/4/2014

Parliamentary Monitoring Group (PMG) (2007). Umsobomvu Youth Fund and National Youth Commission: briefings on Progress. Available on www.pmg.org.za. Accessed on 03/09/2013

Spaul, N. 2014. Matric is failing SA's lost children. Mail \& Guardian. Available at www.mg.co.za. Accessed on 01/09/2014

Tanner, M. (2005). War on Poverty at 50-despite trillions spent, poverty won. Available at www.foxnews.com. Accessed on 04/09/2014 Todaro, P \& Smith SC (2006). Economic Development. 9th edition. New York. Pearson-Addison Wesley.

Trevithick, P. (2005). Social Work Skills. A practice handbook. Open University Press. McGraw-Hill Education, Maidenhead, Berkshire, England.

UNAIDS (2001). Promoting excellence in training. The Regional Training Network (RATN). UNAIDS Best Practice Collection. June. Geneva, Switzerland.

UN-DESA (2014). Youth Social Policy and Development Division. Available on undesadspd.org. Accessed on 04/09/2014. UNDP International Poverty Centre (2006). Poverty in Focus. What is Poverty? Concepts and Measures. Desktop Publishers UNDP (1995). Human Development Report. New York, USA.

UNESCO (2014). Alleviating Youth Poverty. Social and Human Social Sciences. Available at www.unesco.org. Accessed on 13/4/2014 UNESCO (2011). Youth and Poverty. Available at www.un.org. Accessed on 13/4/2014 UNFPA (2013).Youth. Available at www.unfpa.org. Accessed on 01/09/2014 Belmont, CA: Brooks/Cole.

United Nations (2014). A new global partnership: Eradicate Poverty and Transform Economies through Sustainable Development: The Report of the High Level Panel of Eminent Persons on the Post-2015 Development Agenda. United Nations Publications. New York. 